\title{
FACTORS OF DEVELOPMENT OF UZBEK TRADITIONAL THEATER
}

\author{
Boltaboeva U
}

Assistant Professor, Fergana Regional Branch Of Uzbekistan State Institute Of Arts And Culture, Uzbekistan

Madaminov S

Teacher, Fergana Regional Branch Of Uzbekistan State Institute Of Arts And Culture, Uzbekistan

\section{ABSTRACT}

This article discusses the factors of development of traditional Uzbek theater, folk oral dramas and their performers, the role of musicians in art, the new theater under the Soviet regime, the development of cultural heritage, the formation of a new circus and a new theater in Turkestan.

KEYWORDS:- Clown, circus, theater, spectacle, singer, musician, pantamime, ufori, improvisation, performance.

\section{INTRODUCTION}

The concept of traditional Uzbek theater includes elements of spectacle and imitation in the social and cultural life of the people, as well as clowns, amateur art and puppetry, which have been formed and lived for centuries. Historical sources and art historians testify that the art of clowns and amateurs has existed in the Turkestan region for a long time and has existed for centuries as a manifestation of the cultural life of the people. Clowns and amateurs usually performed their plays on the basis of folk oral dramas. These dramas are endlessly numerous and created by the performers themselves. Oral dramas passed from performance to performance, from that group to this group, changing, joining, and shortening. As a result of the fact that they were in oral form, many were forgotten and disappeared as a result of the passage of time, the change of generation of performers. It was only from the beginning of the twentieth century that researchers began to study folk oral dramas and the lives and arts of their performers. From the 1920s and 1930s, the focus shifted to this work, and from the late 1950s onwards, the study and recording of folk oral dramas became more regular. Folk oral drama is the literary basis of traditional Uzbek theater performances, and clowns and amateurs have created and performed their own repertoire based on the popularity and popularity of these oral plays. Folk oral dramas and their performers - the art of clowns and amateurs - existed in all regions of Uzbekistan - in cities and villages. Clowns and hobbyists are usually united into one trade union (association of people belonging to one 
CURRENT RESEARCH JOURNAL OF PEDAGOGICS 2(11): 32-40, November

2021 DOI: https://doi.org/10.37547/pedagogics-crjp-02-11-09

ISSN 2767-3278

(C)2021 Master Journals

\section{Crossref do) 8 Google}

Accepted 25th November, 2021 \& Published 30 ${ }^{\text {th }}$ November, 2021

profession). Korfarmon (master and commander of this profession) led the creative process by directing all the performers in the trade and the trade union - clowns and entertainers, dancers and hangers, and in many cases also hafiz and musicians. Typically, entrepreneurs have strong talents, exemplary service in one field of art, as well as in-depth knowledge of other related fields, ability to manage processes, and a high reputation among the community and the people. Among such entrepreneurs are Muhammadsolih and Bidiyorshum, Zokir Eshan, his student Yusuf Qiziq Shakarjon ogli, famous in the Kokand khanate in the XIX century for their profession and performances, in the Bukhara emirate Boboyor clown, Mizrob clown, Berdiyor Diyorov. There are basically two genres in clown and amateur theater, which are called critique and critique. From an aesthetic point of view, there is no sharp barrier that separates these two genres, but rather complements each other. But both have a primary function: the main task in criticism is to criticize, humor, as well as humor, ridicule the shortcomings of human nature in life, while the primary task is to replace the man - man and woman, cat or child, creature, behavior is considered. It is natural for a show in the genre of criticism to have mixed traits of criticism. For example, acting in the genre of muqallid, adherence to its conditions, encourages the traditional theatrical actor to find the image in the critical genre, to explore the performer in the life simulation, to avoid dry imitation (naturalism) in the genre of imitation, to exaggerate, exaggerate, his actions with trying to convince and make the audience laugh. So both genres require each other. The first sign that a clown and amateur is a clown and an amateur is a long hat with a pointed tip on the top. As the clown and entertainer enter the performance, he wears and puts on make-up in accordance with the story and images of the work, using elements such as artificial beards. Clowns and comedians have also used the performance mask, which has been preserved in the Uzbek traditional theater for centuries. Due to the fact that men play the role of women in the traditional Uzbek theater, special attention is paid to the problems of imitation of women - behavior, voice, head, makeup, special items such as women's wigs, shoes. The location, environment, and time of the event are expressed in highly conditional ways. The repertoire of the traditional Uzbek theater differs from the oral theaters of many nations in the number of themes, plays, and in some cases the number of members of the troupe. In particular, his repertoire includes various aspects of the daily life of the people - the judiciary, the activities of judges and treasury, the market, trade, impurity in the distribution of water to the rich and poor, theft, usury, madrassas, schools, education and upbringing. such topics as fraud among the clergy, deception of the common people, the khan's palace, the dialogue of the people with the colonial administration. This is evident from the activities of the troupes and their repertoire.

I know, Muhammad Salih Bidiyorshum is a wellknown artist who created and operated a traditional theater school in the Fergana Valley. She lived and worked during the reign of Umarkhan (1787-1822), the husband of the famous poetess Nodirabegim from Kokand khans, and her son Muhammad Alikhan (Madalikhan, 1810-1842). known to be. In his troupe, Bidiyor Shum has focused on a number of performances, including Mudarris, Distribution or Inheritance, and other issues related to the life of the country and the violation of women's rights. In the play "Mudarris", the filthy behavior and inferiority of a teacher who leads a madrassa and teaches theology and religion is ridiculed. For example, the play describes the extent to which the teacher satisfies the request of those who come to the madrasa to ask for a room. He behaves inappropriately to the beautiful mullah 
CURRENT RESEARCH JOURNAL OF PEDAGOGICS 2(11): 32-40, November

2021 DOI: https://doi.org/10.37547/pedagogics-crjp-02-11-09

ISSN 2767-3278

(C)2021 Master Journals

\section{Crossref do) 8 Google}

Accepted 25th November, 2021 \& Published 30 ${ }^{\text {th }}$ November, 2021

who is reciting in his hand. The angry mullahs want to take revenge on the teacher and wait for the time, punishing him for his inappropriate behavior and pouring water in a bucket over him. The play "Land Distribution or Inheritance" depicts the abuse of women as the scene of a father's inheritance being divided between sons and daughters. Judges and scholars, ignoring the fact that according to the Shari'a, a woman is ordered to give only one-eighth of the inheritance, try to do good to the female heir, to show a part of the land, and in fact treat her with inappropriate and immoral behavior.In art, the leader of a group of musicians is called a mehtar. Usually, master musicians were able to play trumpets, horns, and drums skillfully. The troupe he led consisted of about thirty people, including Rizo Qiiq, Sa'di Mahsum, Normat Qiziq, Boybuva Qiziq, Momin Qishloq, Bahrom Qiziq, Usman Qiziq, Shomat Qiziq, Davlat Qiziq, Holmat Qiziq, Kalsariq Qiziq, Avliyakhan Qiziq. The troupe's repertoire includes "Khan Hajvi", "Khanga Ariza", "Zarkokil", "Mozor", "Avliyo", "Sirkataroq azizlar", "Haji kampir", "Qalandarlar", "Dorbozlik", "Khatna", "Yomon uka", "Four Madmen or Azoyimkhan", "She Went Out", "The Bride Dropped", "Husband and Wife", "Chairman", "Mirobboshi", "Uytesharlar", "Boy and Mardikor" and many other poems were performed. . From the names of these poems, it is clear that he paid attention to the important topics of his time, threw them into public discussion and made a joke. For example, in the seemingly humorous performance of "Kelin Tushirdi", the theme of people's lives, which leads to tragic, tragic consequences or disappointments, is raised. According to the belief that has become a centuries-old custom in the way of life of the people, a girl and a boy are married without seeing each other. Only in Goshang does the bridegroom witness that the bride is a helpless, moreover, older woman. The play "Graveyard" takes into account the same theme and exposes the actions of depraved sheikhs and perverted men (who dream of stealing) who are young women who have come to the holy graveyard for salvation (having children and other trades). One of the mature businessmen who continued the school of Zokir Eshan was Saadi Makhsum (year of birth unknown, died 1899). His father, Zulfiqor, was a fan of the Margilan bird. The potential of many entrepreneurs is also present in Saadi Mahsum, who has been a master of dance and music as well as creating entertainment shows. For example, Joseph is a teacher of curiosity. Yusufjon continued his knowledge and skills in the field of art on the basis of the centuries-old traditions of his teachers and folk theater, starting with countless folk poems, songs, "Shashmaqom" tracks, circle and drum methods, "Big Game", folk dances in general. Seeing his talent, Saadi, in his old age, handed over his position on the trade union council to Yusuf and announced him as an employer. The beginning of Yusufjan Qiziq's life and creative activity coincided with the Russian occupation of Turkestan. During this period, the Kokand Khanate was abolished today, its position as the center of culture, especially the residence of folk artists, was severely damaged, and the troupes were disbanded. On top of that, many of the performers in the Zokir Eshan troupe are too old to be able to return to the profession. Yusufjon formed his own troupe in the interesting city of Margilan and continued his artistic activity. He made creative trips to the Emirate of Bukhara, Khiva Khanate, East Turkestan-Kashgar, Gulja, Yorkent and St. Petersburg (1909). In addition to traditional theatrical samples, his troupe's repertoire included many plays created by him on a modern theme. Among them are such works as "Victor the rich man's prayer", "Libra", "Election of the Fifty Heads", "Saydazimboy's trip to Moscow". In the show "Tarozibon" it is ridiculed that the rich cotton grower was in debt 
CURRENT RESEARCH JOURNAL OF PEDAGOGICS 2(11): 32-40, November

2021 DOI: https://doi.org/10.37547/pedagogics-crjp-02-11-09

ISSN 2767-3278

(C)2021 Master Journals

\section{Crossref do) 8 Google}

Accepted 25th November, 2021 \& Published 30 ${ }^{\text {th }}$ November, 2021

after deducting its moisture, hay waste and humus from the farmer's products brought to the cotton factory for sale by the rich cotton grower. It is criticized that in the conditions of colonial regimes, the city inspector (bailiff) transferred an unworthy person to the post of chief in exchange for a bribe. Yusufjon Qiziq was an entrepreneur in his troupe, as well as artists and clowns from all over Turkestan, singers and musicians, creative people in general, as well as the public and the people as masters and masters. Since the beginning of the twentieth century, in connection with the formation of a new circus and a new theater in Turkestan, Yusufjon's interesting troupe, personally, began the process of change in his creative activity. This process took place primarily on the example of the cooperation of the new Uzbek circus and the traditional theater in the creation of a new circus interest - the Uzbek circus clown. A new circus with a closed roof and a tent was set up in Europe, from where it came to Russia, and after Turkestan was invaded by Russia. European and Russian traveling circus troupes often make creative trips to Turkestan, setting a good example for circus enthusiasts. Based on its conditions, the new circus adapts many types and genres of folk arts and sports - hobby, "horse game" and horseback riding, wire, suspension, pole vault, wrestling, wrestling, animal and animal training, lollipop. Takes Yusuf was invited to the circus of Mullaboy Mansurov, which was first organized in Tashkent in 1902 in Uzbekistan. Yusuf Curious works in this circus with his troupe. Yusufjon is also interested in the creation of a new theater in the conditions of the Soviet regime, the mastery of cultural heritage, the creation of modern art through learning from the elements of Uzbek dance, music, traditional theater. Mastering the elements of national traditional theater at the Uzbek State Theater under the direction of Mannon Uygur (19211927), concert-ethnographic ensemble under the direction of Muhiddin-qori Yakubov (19261929) mastering the Uzbek national dance - "Big Game", women's dances, lapar art. The scientist works closely with Kamilov. She personally teaches Tamarakhonim to master and perform Uzbek songs, lapar and dances. Thus, from the end of the 19th century to the end of his life, Yusufjon was a well-known comedian and an unparalleled entrepreneur, as well as a living source who mastered the Uzbek traditional art heritage. has a special place in history. It is known that traditional folk theater has long been popular in other regions of Uzbekistan - in the cities and villages of the Bukhara Emirate and Khiva Khanate, and there are reports about this in various sources. However, the names of those involved in this type of art, the work they performed and their names are still unknown. We have only information about the life and work of Udar, his repertoire, the clowns who have lived and worked since the XIX century. One of them was Boboyor, a clown who lived and worked in the villages of Mount Miraki in the Bukhara Emirate in the middle of the 19th century. According to Berdiyor Diyorov, Boboyor's grandson, there were clown musicians in Boboyor's town, such as Muzrob Mashara, Shadi Kalla, Muhammad Khaliq, and Sherkul Khirri (his voice was "Khir-Khir"). Baboyor's work was continued by his student Mizrob Maskhara (1848-1918) with his troupe. His troupe included Muhammad Diyar, Muhammad Nazar, Bota Daroz, a clown named Turdili, players named Mavloncha and Muhammadali, and artists named Avazmurod (doirachi), Ergash (trumpet player), Rozi (trumpet player). Later, Berdiyor Diyorov and Tursuibobo Khalikov joined the troupe. Berdiyor Diyorov (18841968), who continued to make fun of Mizrob, is a reliable source in determining the clowns, their troupe and repertoire from the time of Boboyor to the period in which he lived and worked. According to him, both Boboyor's group and the 
CURRENT RESEARCH JOURNAL OF PEDAGOGICS 2(11): 32-40, November

2021 DOI: https://doi.org/10.37547/pedagogics-crjp-02-11-09

ISSN 2767-3278

(C)2021 Master Journals

\section{Crossref do) 8 Google}

Accepted 25th November, 2021 \& Published 30 ${ }^{\text {th }}$ November, 2021

troupe he works for are "Eshoni rais", "Sudkhor", "Sartarosh", "Boz magazini", "Hirmon kotarish", "Juvozrang", "Mirob", "Ugrilik", "Tegirmonchi", "Brother Sudkhor gives his life" has always been in the repertoire. The art of clowns is performed in all regions of the Bukhara Emirate, including cities and surrounding villages such as Denau, Nurata, Boysun. In Boysun, there was a trade union led by Kal Homid, and the team consisted of artists such as Usto Mirzo, Usto Sadiq, Usto Layla, Ramazan Hirri. The troupe's repertoire included performances such as "My brother Sudkhor gives life", "Horse game", "Ugri", "Barber", "Bear game", "Hook", "Dor game", "Cigarette", "Straw game". Similar clown communities existed in many other urban villages as well. It is natural that Khorezm, a place of Uzbek statehood and ancient culture, also has a traditional theatrical culture. However, in the conditions of the late XIX and early XX centuries, when there was a large group of literature and art - poetry, music, dance groups, the troupe of clowns was not caught in the palace. Only in the khan's palace was there a peculiar curiosity. Small, mostly clown gangs of two people operated in remote towns and villages.) Among them were Quvvat Kalta (1827-1910) and Matyokub Kor (1833-1920) and Boltaqul Clown (1853-) in the villages of Kipchak and Kilichvoy of the Mangit, known throughout Khorezm. 1933) and Kirkin (18291915), brothers Eshmat (1853-1933) and Dosmat (1878 1923). The performances of the Khorezmian clowns were muqallid - a pantomime, a play performed by a clown, without music, only with words and actions. The comedy, which is performed in Dorboz, consists of a multi-part show called "a memorable (line, series) game". In the pantomime category of performances, the subject is more birds and animals, sometimes humans and inanimate objects. Since the aim is to express the qualities of human nature by means of a figurative gesture, the performance follows the process of creating an artistic image, not the exact method of imitation. In this sense, Khorezm theatrical pantomimes remind us of a well-known genre of parables from literature. Pantomime includes "Goat Game", "Cat (Cat) Game", "Tustovuq", "Baby (Fish Bird)", "Sipsa (Broom) Game", "Kumpishik (Rainbow)", "Rooster Fighting", "Old Woman","Poppy","Gambler "are among them. The pantomimes in their performance require great skill from the clown - the ability to create a clear artistic image in the expression of the norm, figurative thought in imitation. The performances, performed by a clown, were performed by solo clowns. Among such clowns are Buvajon Tok-Tok (1870-1940) and Khudoibergan Tok-Tok Abdurahmanov (born in 1900). In each of their performances, they described two or even more characters by changing their voices and finding appropriate action. Such performances include comedy stories such as "I became a student of Holvach", "Hokki tora", "My mother sent me to the fire". The "Dangerous Game" series includes interrelated, sequential pantomimes, jokes, or critical plays. Typically, the performances of "Dangerous Game" began with the dances "Norim-norim" and "Clown Uforisi" ("Flower Ufori"), which are performed with gusto. After the dance, the show went straight to the performance. For example, in the "Khankali Gavzanboy" clown, the merchant Gavzanboy meets a robber on a trip and tries to present himself as poor, knowing many rich people and their wealth. No matter how hard he tries, his efforts are in vain. The roadster snatches Gavzanboy's belongings and forces him to come to the game out of "joy", ignoring the fact that he has saved him from the worries of the world. Another similar show was connected to this show, for example, "Khachatur Armani". In this play, as the merchant Khachatur's cargo ship sank in a storm and was separated from its 
CURRENT RESEARCH JOURNAL OF PEDAGOGICS 2(11): 32-40, November

2021 DOI: https://doi.org/10.37547/pedagogics-crjp-02-11-09

ISSN 2767-3278

(C)2021 Master Journals

\section{Crossref doi) 81 Google}

Accepted 25th November, 2021 \& Published 30 ${ }^{\text {th }}$ November, 2021

owner's property, more attention is paid to language, speech, and conversation through humor. It is known that Armenian traders coming and going to Central Asia spoke the language of neighboring Azerbaijan. This language is close to the Khorezm dialect. The language of the work, built on this closeness, has become an interesting subject of improvisation and mastery in the performance of the clown. In this way, the series (series) of performances was performed by clowns depending on the situation and the needs of the audience. The participation and role of the art of clowns in the formation of the ancient circus ("horse game", trained horses, animals, animals in general, performances with puppets) and the formation of a new circus is an important event. From time immemorial, clowns have participated in various circus performances, as well as in some of its genres. For example, a clown was not only a clown, but also a "besuyak", a juggler or a joker, and, conversely, a joker and a joker. For example, the famous rider, one of the organizers of the new Uzbek circus, Karim Zarifov (1890-1960), who began his career as a hangman and five-legged friend, became known in the new Uzbek circus in the 1920s and 1930s as "Karim Qiziq". founded the genre. According to the requirements of the new circus, the Zarifovs will perform in a modern Uzbek clown's head and make-up "What does Karim say?" on the basis of a general program called the so-called topical issues of the period. Muborakhon Zarifova (1906-1992) was the first Uzbek female amateur in the circus. Along with her husband, she was known for her interesting performances on topics such as "Who's Who," "Toothache," and "Song and Ghost." In the circus, the Zarifovs continued their interest in the clown - Akrom Yusupov (19051975) and raised it to a new level. He began his creative career in the circus as a hangman and porter (1930-44), and from 1945 rose to the level of a leading and famous fan of the Uzbek circus. Thus, the Uzbek clown and comedy art lived as a manifestation of the traditional folk theater until the twentieth century. Its rich folk treasures serve as an invaluable resource in the study of national cultural heritage and in the development of new theaters, circuses and dances, as well as modern art forms.

\section{REFERENCES}

1. Rakhmonov M., Tulakhojaeva M. T., Muxtorov I. A. History of the Uzbek National AcademicDrama Theater. - T., 2003.

2. Rizaev Sh. Jadid drama. - T .: Sharq, 1997.

3. Independence and National Theater (collection). - T .: Yangi asr avlodi, 2002.

4. Tursunboev S. History of theater. - $\mathrm{T}$.: Bilim, 2005.

5. Tursunov T. Scene and time. - T .: Yangi asr avlodi, 2007.

6. Islomov $\mathrm{T}$. History and scene. - $\mathrm{T}$ : $\mathrm{G}^{\prime}$. Gulom Publishing House of Literature and Art, 1998.

7. Yunusov, G. X., Juraev, I., \& Ahmedov, R. The European Journal of Arts, Issue $1 / 2020$.

8. Yunusov, G., Juraev, I., \& Ahmedov, R. (2020). A look at the regional seasonal folklore and their origin. The role and importance of folklore in the development of dance art. European journal of arts, (1), 121-124.

9. Yunusov, G. Y., Parpiev, A., \& Ernazarov, Z. (2021). A look at samples of uzbek folklore. ACADEMICIA: An International Multidisciplinary Research Journal, 11(5), 9-14.

10. Болтабоева, У., \& Дехқонов, Р. (2021). 
CURRENT RESEARCH JOURNAL OF PEDAGOGICS 2(11): 32-40, November

2021 DOI: https://doi.org/10.37547/pedagogics-crjp-02-11-09

ISSN 2767-3278

(C)2021 Master Journals

Crossref do: 81 Google

Accepted 25th November, 2021 \& Published 30 ${ }^{\text {th }}$ November, 2021

Хаётийлик ва хаққонийлик драматик acap, режиссура, актёрлик махорати асоси. Oriental art and culture, 2(3), 134141.

11. Dadaboev, Y., \& Dehqonov, R. Hordo Structures in Central Asian Architecture.

12. Талабоев, А. Н. (2019). Ўзбек миллий анъанавий ижрочилик санъатида махаллий услублар. Перекрёсток культуры, 1(4).

13. Ўғли, Х. И. Т. (2020). Ўзбек солиқ терминларининг аффиксация усули билан ясалиши. Oriental art and culture, (V).

14. Ўғли, Х. И. Т. (2020). Тилшуносликда солиқ-божхона терминологиясининг тадқиқи. Oriental art and culture, (V).

15. Ismoilova, N., \& Habibjonov, I. (2021). Kitob va kitobxonlik-inson manaviyatining kozgusi. Oriental art and culture, 2(1), 159166.

16. Normatova, M., \& Ikromjon, X. (2021). "Qutadg'u bilig" ikki jahonni tutishga ochuvchi yo'l. Oriental Art and Culture, (6).

17. Хабибжонов, И. Т. Ў. (2021). Солиқбожхона терминологиясида дублетлик ва уни тартибга солиш масалалари. Scientific progress, 1(6), 842-846.

18. Ismoilova, N., \& Habibjonov, I. (2021). Kitob va kitobxonlik-inson manaviyatining kozgusi. Oriental Art and Culture, 2(1), 159-166.

19. Habibjonov, I. (2020). Syntactic design of uzbek tax and customs terminology. Journal of Advanced Research in Dynamical and Control Systems, 12(2), 2910-2915.

20. Oglu, H. I. T. (2020). Formation of uzbek tax and customs terms (on the example of materials on the history of language). Academicia: an international multidisciplinary research journal, 10(12), 1308-1313.

21. Рўзиева, Г., \& Хабибжонов, И. (2021). Садр зиё кутубхонаси. Oriental art and culture, (6).

22. Қурбонова, М. (2021). Аёллар санъати: кеча ва бугун. Oriental art and culture, 2(3), 62-75.

23. Турсунов, Б. (2020). Чолғу ижрочилиги тарихига бир назар. Oriental art and culture, (V).

24. Ғофурова, Б. (2020). Актёрнинг нутқини такомиллаштиришда инновацион технологияларнинг ахамияти. Oriental art and culture, (V).

25. Парпиев, А. (2021). Жадидчи обиджон махмудовнинг фаолиятидаги янги қирралар. Нодавлат қўғирчоқ театрларида актёрлик санъати масалалари. Oriental Art and Culture, (6).

26. Мадалиев, А. (2021). Кўғирчоқ театри тарихига назар. Oriental art and culture, 2(3), 125-133.

27. Мадалиев, А. (2021). Кўғирчоқ театри актёрининг пластик имкониятлари. Oriental Art and Culture, (7), 49-57.

28. Мадалиев, А. (2021). Oriental Art and Culture, (7), 37-48.

29. Омоновна, С. Х. (2021). Маданият ва маънавият масалаларида тарихий илдизлар излари. Oriental Art and Culture, (7), 244-253.

30. Омоновна, С. Х. (2021). Глобаллашув жараёнида ахборот оқимининг ёшлар маънавиятига таъсири хусусида. Oriental Art and Culture, (7), 217-224.

31. Омоновна, Х. С. (2020). Тарихий қўлёзма 
CURRENT RESEARCH JOURNAL OF PEDAGOGICS 2(11): 32-40, November

2021 DOI: https://doi.org/10.37547/pedagogics-crjp-02-11-09

ISSN 2767-3278

(C)2021 Master Journals

Crossref do: 81 Google

Accepted 25th November, 2021 \& Published 30th November, 2021

манбаларни консерватция-реставрация қилиш жараёнлари хусусида. Oriental Art and Culture, (V).

32. Омоновна, С. Х. (2019). Агар бола сизни «Эшитмаса»... Современное образование (Узбекистан), (4 (77)), 58-63.

33. Омоновна, С. Х. (2018). Ўкувчилар тарбиясини шакллантиришда отаоналарга педагогик билим бериш тизимининг ахамияти. Современное образование (Узбекистан), (5).

34. Омоновна, С. Х. (2018). «Бебош бола» синдроми ёхуд нега болалар асабийлашади? Современное образование (Узбекистан), (11).

35. Солиева, Х. О. (2018). Взгляды ибн сино на медицинское воспитание молодёжи. Актуальные научные исследования в современном мире, (5-6), 56-60.

36. Shermatova, X. (2020). Musiqa nazariyasining o'ziga xos xususiyatlari. Oriental Art and Culture, (V).

37. ШЕРМАТОВА, Х. К. (2015). Народная музыка как средство музыкальноэстетического воспитания школьников. In Юность и Знания-Гарантия Успеха2015 (pp. 318-316).

38. Шерматова, Х. К. (2020). Формирование музыкальной культуры молодёжи. Проблемы современной науки и образования, (12-1 (157)), 117-119.

39. Shermatova, X. (2020). Musiqa nazariyasining o'ziga xos xususiyatlari. Oriental Art and Culture, (V).

40. Пўлатов, Р. (2020). «Мирзо улуғбек» трагедиясининг яратилиши тарихи. Oriental Art and Culture, (V).

41. Ismoilova, M. (2020). Cholg'u ijrochiligida notaga qarab ijro qilish. Oriental Art and
Culture, (V).

42. Болтабоева, У. (2021). Бўлажак актёрларни тарбиялашда педагогик ёндашувлар. Oriental Art and Culture, 2(3), 88-98.

43. Болтабоева, У., \& Дехқонов, Р. (2021). Хаётийлик ва хаққонийлик драматик acap, режиссура, актёрлик махорати асоси. Oriental Art and Culture, 2(3), 134141.

44. Boltaboeva, U., \& Xalilov, Y. (2021). Teatr san'atining o 'ziga xos xususiyatlari. Oriental Art and Culture, 2(3), 40-48.

45. Boltaboyeva, U., \& Yu, K. (2021). The director's work on monologue and miseen-scenes. Current research journal of pedagogics (2767-3278), 2(10), 71-77.

46. Хатамова, Ё., \& Болтабоева, У. (2019). Нутқ техникасини такомиллаштиришда халқ оғзаки ижодидан фойдаланиш усуллари. Oriental Art and Culture, (IV (1)), 50-52.

47. Усмонов, Ш. Ю. (2021). Режиссёрнинг рассом билан ишлаши. Oriental Art and Culture, (6).

48. Boltaboeva, U., Abdunazarov, Z., \& Usmonov, S. (2021). The balance of language and speech in the Uzbek theater. Asian journal of multidimensional research, 10(4), 788-792.

49. Abdunazarov, Z. (2021). Hamza hakimzoda niyoziy dramaturgiyasi. Oriental Art and Culture, 2(3), 170-178.

50. Хайдаров, А. (2021). Ёшларимизнинг эстетик баркамол бўлиб улғайишида ўзбек халқ оғзаки ижоди намуналарининг ўрни. Oriental Art and Culture, (6).

51. Асқарова, М. (2021). Адабий жараённинг 
CURRENT RESEARCH JOURNAL OF PEDAGOGICS 2(11): 32-40, November

2021 DOI: https://doi.org/10.37547/pedagogics-crjp-02-11-09

ISSN 2767-3278

(C)2021 Master Journals

Crossref dof 81 Google

Accepted 25th November, 2021 \& Published 30th November, 2021

зукко тадқиқотчиси. Oriental Art and Culture, (7), 209-216.

52. Askarova, M. (2020). Homil yakubov's views on navoi studies. Academicia: an international multidisciplinary research journal, 10(12), 788-792.

53. Askarova, M. (2021). Homil Yakubov's views on Oybek lyrics. ACADEMICIA: An International Multidisciplinary Research Journal, 11(3), 2412-2415. 